\title{
Persistence Ability of Citrobacter Isolated from Dairy Products
}

\author{
R.Kh. Gairabekova ${ }^{1, *}$ \\ ${ }^{1}$ Chechen State University, Department of Microbiology and Biology Medical Institute, Grozny, 366300, Russia \\ *Corresponding author. Email: ruslan.sarmat@mail.ru
}

\begin{abstract}
A persistence ability is the capacity of pathogenic and opportunistic bacteria to survive in the aggressive internal environment of a macroorganism and is an important feature for these groups of microorganisms. The paper aims to establish whether the target Citrobacter cultures, once isolated from home-produced dairy products, have adhesive strength and hemolytic activity.
\end{abstract}

Keywords: persistence, bacteria, culture, strain, adhesion, hemolysin, thiol, agar, lysozyme, antilysozyme, hemagglutination.

\section{INTRODUCTION}

The ability of pathogenic and opportunistic microorganisms to remain viable under the aggressive internal environment of a macroorganism is a paramount necessary and important survival-driven attribute. This ability largely determines the pathogenic properties of these bacteria. Pathogenicity is a complex factor made up of a large number of microorganism abilities that are diverse in their effect on host organisms. Pathogenicity is an inherited species trait that is fixed in the genome of a phenotypic carrier, resulting from adaptation. It arises during the evolution of a parasite, i.e. it is a genotypic trait that indicates the capacity of a microorganism to penetrate into a macroorganism (infectivity) and multiply in it (invasiveness), causing the development of multiple pathological processes to occur in an infected organism during a disease.

The paper presents the findings showing the ability of Citrobacter cultures to hemagglutination and hemolysis. They were divided into two groups: the first group involved strains cultured from dairy products, the second group - cultures isolated from small ruminants.

\section{MATERIAL AND METHODS}

The paper attempts to identify the factors that allow Citrobacter to survive in the internal environment of animals and humans, which is an aggressive environment for microorganisms. With this in view, 59 strains of $C$. freundii were tested once isolated from dairy products $[9,10]$ and 51 strains cultured from small ruminants to detect bacterial hemolysin and adhesive strength. $1.5 \%$ beef-extract agar-agar (solid nutrient medium) was used to cultivate the target $C$. strains. $0.7 \%$ beef-extract agar-agar (semi-liquid nutrient medium) was also used to create a second layer on top of solid agar. Incubation lasted 18-24 hours in a thermostat at $37{ }^{\circ} \mathrm{C}$. Hemolytic abilities in the target bacteria were detected with nutrient agar supplemented with 3-5\% rabbit erythrocytes trebly rinsed in Hanks solution [4-8, 11]. To identify hemolysins being produced subject to the thiol present in the blood agar, $0.002 \%$ L-cysteine (thiol-dependent hemolysins) was added to the blood agar [2, 3].

The adhesive strength in Citrobacter was found in a $3 \%$ blood cell hemagglutinin assay (red cells were freshly-received from a ram) in the presence and absence of D-mannose. The ability to agglutinate in the presence of D-mannose was considered as the presence of D-mannose-resistant adhesive activity in the target bacteria [4-8].

Lysozyme activity in the target $C$. cultures was evaluated on $1.5 \%$ nutrient agar by the method of delayed antagonism after Bukharin et al. [1]. The cultures were incubated at $37{ }^{\circ} \mathrm{C}$ for $18-24$ hours, then 
the grown colonies were treated with chloroform vapors for 10 minutes, after which washed daily Micrococcus luteus var. Lysodeikticus cultures was twofold layered onto the target cultures in the dishes. A lysis zone found to be present around the inoculated strains of the target cultures signifies lysozyme activity.

The antilysozyme activity of Citrobacter isolated from various sources was determined by the method of Bukharin et al. [1] based on the micrococcal growth around the colonies of the target cultures on Petri dishes with different lysozyme content. The method determines the quantitative and qualitative productivity of antilysozyme activity in the target cultures.

\section{FINDINGS}

The tests to detect the Citrobacter ability to agglutinate sheep erythrocytes in the absence of Dmannose showed that 41 strains $(69.5 \%)$ out of $59 C$. cultures isolated from dairy products had agglutinable capacity, so did $28(54.9 \%)$ out of 51 C. strains isolated from small ruminants (Table 1).

Table 1. Citrobacter ability for hemagglutination

\begin{tabular}{|l|l|l|l|}
\hline \multirow{2}{*}{$\begin{array}{l}\text { Source of C. } \\
\text { strains }\end{array}$} & \multirow{2}{*}{$\begin{array}{l}\text { No. } \\
\text { strains }\end{array}$} & Hemagglutinating strains \\
\cline { 3 - 4 } & 59 & 41 & $\%$ \\
\hline Dairy products & 59 & 28 & 69.5 \\
\hline Ruminants & 51 & 54.9 \\
\hline
\end{tabular}

Laboratory tests aimed at establishing whether the Citrobacter cultures can agglutinate sheep erythrocytes in the presence of D-mannose (D-mannose-resistant hemagglutinating ability) identified that 4 strains $(6.8 \%)$ had this trait out of 59 Citrobacter strains cultured from dairy products and 6 cultures $(11.76 \%)$ out of 51 Citrobacter cultures isolated from small ruminants (Table 2).

Table 2. Ability for D-mannose-resistant hemagglutination among various Citrobacter cultures

\begin{tabular}{|l|l|l|l|}
\hline Source of $C$. & \multirow{2}{*}{$\begin{array}{l}\text { No. } \\
\text { strains }\end{array}$} & \multicolumn{2}{|l|}{ Hemagglutinating strains } \\
\cline { 3 - 4 } & strains & Number & $\%$ \\
\hline Dairy products & 59 & 4 & 6.8 \\
\hline Ruminants & 51 & 6 & 11.76 \\
\hline
\end{tabular}

Besides, various Citrobacter cultures were tested for hemolytic activity. The tests showed that out of 59 Citrobacter strains isolated from dairy products 34 cultures $(57.6 \%)$ had the ability to lyse rabbit erythrocytes, and out of 51 Citrobacter strains cultured from small ruminants, this trait was found to be present in 30 cultures $(58.8 \%$ ) (Table 3$)$.
Table 3. Distribution of hemolytic activity among various Citrobacter cultures

\begin{tabular}{|l|l|l|l|}
\hline Source of C. & \multirow{2}{*}{$\begin{array}{l}\text { No. } \\
\text { strains }\end{array}$} & \multicolumn{2}{|l|}{ Hemolysin-producing strains } \\
\cline { 3 - 4 } & strains & Number & $\%$ \\
\hline Dairy products & 59 & 34 & 57.6 \\
\hline Ruminants & 51 & 30 & 58.8 \\
\hline
\end{tabular}

The ability of the target Citrobacter cultures to produce hemolysins, whose secretion depends on thiolcontaining components present in a nutrient medium thiol-dependent hemolytic activity that was first described by Albesa et al. (1985) [2, 3] for Klebsiella cultures capable of thiol-dependent lysis of rabbit erythrocytes, made it possible to establish that these hemolysins were inherent in 7 strains out of 59 tested Citrobacter cultures isolated from dairy products, which amounted to $11.9 \%$, as can be seen from the data (Table 4). Fifteen strains had thiol-dependent hemolytic activity, amounting to $29.4 \%$, out of 51 Citrobacter cultures isolated from small ruminants on the territory of the Chechen Republic. (Table 4).

Table 4. Thiol-dependent hemolytic activity in various Citrobacter cultures

\begin{tabular}{|l|l|l|l|}
\hline Source of C. & No. & Hemolysin-producing strains \\
\cline { 3 - 4 } strains & strains & Number & $\%$ \\
\hline Dairy products & 59 & 7 & 11.9 \\
\hline Ruminants & 51 & 15 & 29.4 \\
\hline
\end{tabular}

There were 13 strains secreting lysozyme out of 59 Citrobacter cultures isolated from dairy products, making up. $22.03 \%$, while 8 strains were reported to produce lysozyme, making up $15.69 \%$ out of 51 cultures isolated from small ruminants. (Table 5).

Table 5. Lysozyme activity in various Citrobacter cultures

\begin{tabular}{|l|l|l|l|}
\hline Source of $C$. & \multirow{2}{*}{$\begin{array}{l}\text { No. } \\
\text { strains }\end{array}$} & Hemolysin-producing strains \\
\cline { 3 - 4 } & strains & Number & $\%$ \\
\hline Dairy products & 59 & 13 & 22.03 \\
\hline Ruminants & 51 & 8 & 15.69 \\
\hline
\end{tabular}

The ability to produce antilysozyme was found to be present in 27 strains $(45.76 \%)$ out of 59 isolated from dairy products and tested cultures, whereas 39 strains $(76.47 \%)$ out of 51 cultures isolated from small ruminants were reported to have antilysozyme activity. (Table 6). 
Table 6. Antilysozyme activity in various Citrobacter cultures

\begin{tabular}{|l|l|l|l|}
\hline Source of $C$. & No. & Hemolysin-producing strains \\
\cline { 3 - 4 } strains & strains & Number & $\%$ \\
\hline Dairy products & 59 & 27 & 45.76 \\
\hline Ruminants & 51 & 39 & 76.47 \\
\hline
\end{tabular}

As shown by the tests, the quantitative exposure to antilysozyme (i.e. the concentration of produced antilysozyme) in the target Citrobacter cultures ranges from 1 to $6 \mu \mathrm{g} / \mathrm{ml}$.

\section{DISCUSSION}

Thus, the findings demonstrate that adhesive strength found to be present in the two groups of the target Citrobacter cultures isolated from dairy products and from small ruminants is a fairly common feature. Thus, $69.5 \%$ of Citrobacter cultured from dairy products possessed this trait, and $54.9 \%$ of strains among those isolated from small ruminants were reported to have this trait.

The D-mannose-resistant hemagglutinating ability identified in the target Citrobacter cultures made it possible to establish that this trait is not often found in these microorganisms. Thus, among the Citrobacter cultures isolated from dairy products, 4 cultures $(6.8 \%)$ were reported to have this trait, and among those cultured from small ruminants $-6(11.76 \%)$.

The ability to synthesize hemolysins is one of the significant properties for pathogenic and opportunistic microorganisms. Thus, the tests showed that out of 59 strains of Citrobacter, the ability to lyse rabbit erythrocytes was characteristic of 34 cultures $(57.6 \%)$, and of 51 strains of Citrobacter isolated from small ruminants, 30 cultures $(58.8 \%)$ had this trait.

The capacity of the target Citrobacter cultures to produce hemolysins, whose secretion depends on thiolcontaining components present in a nutrient medium made it possible to establish that these hemolysins were inherent in 7 strains out of 59 tested Citrobacter strains cultured from dairy products, which amounted to 11.9 $\%$, out of 51 Citrobacter cultures isolated from small ruminants, 15 strains were characterized by thioldependent hemolytic activity, i.e. $29.4 \%$

There were 13 strains (22.03\%) secreting lysozyme out of 59 Citrobacter cultures isolated from dairy products, while 8 strains $(15.69 \%)$ were found to produce lysozyme, out of 51 cultures isolated from small ruminants. The capacity to produce antilysozyme was found to be present in 27 strains $(45.76 \%)$ out of 59 isolated from dairy products and in 39 strains $(76.47 \%)$ out of 51 cultures isolated from small ruminants.

\section{CONCLUSION}

Adhesive strength in the two groups of Citrobacter cultures isolated from dairy products and from small ruminants is a fairly common trait. Thus, $69.5 \%$ of the Citrobacter cultured from dairy products possessed adhesiveness, and among the strains isolated from small ruminants, $54.9 \%$ were characterized by the presence of this trait. Thus, among the Citrobacter isolated from dairy products, 4 cultures $(6.8 \%)$ were characterized by D-mannose-resistant hemagglutinating ability, and among those cultured from small ruminants -6 $(11.76 \%)$.

The ability to lyse rabbit erythrocytes was characteristic of 34 strains $(57.6 \%)$ cultured from dairy products, and 30 cultures of 51 Citrobacter strains isolated from small ruminants $(58.8 \%)$. Thioldependent hemolysins were inherent in 7 strains from 59 target Citrobacter strains cultured from dairy products, which amounted to $11.9 \%$, and 15 strains from 51 Citrobacter cultures isolated from small ruminants, i.e. $29.4 \%$.

There were 13 strains (22.03\%) secreting lysozyme out of 59 Citrobacter cultures isolated from dairy products, and among 51 cultures isolated from small ruminants, 8 strains $(15.69 \%)$ produced lysozyme. The ability to produce antilysozyme was found to be present in 27 strains $(45.76 \%)$ out of 59 isolated from dairy products and tested cultures, and in 39 strains $(76.47 \%)$ out of 51 cultures isolated from small ruminants.

\section{REFERENCES}

[1] I.M. Gabrilovich, R.Kh. Gairabekov, T.Ch Zhugova et al., Lysozyme and antilysozyme activities in opportunistic Enterobacteriaceae, in Abstracts of the 18 Congress of the All-Russian Society of Epidemiologists, Microbiologists and Parasitologists, Alma-Ata, 1989, pp. 163-164.

[2] I.M. Gabrilovich, R.Kh. Gairabekov, V.B. Boziev, M.V. Zarochentsev, Thiol-dependent hemolysins in opportunistic Enterobacteriaceae, in: 2nd AllRussian Conference on Bacterial Toxins, Jurmala. 1989, p. 24.

[3] I.M. Gabrilovich, R.Kh. Gairabekov, M.A. Sheojev, Thiol-dependent hemolysins as a factor of pathogenicity of Citrobacter and Serratia bacteria, in: Proc. of the Conference on Persistence of Bacteria Kuibyshev, 1990, pp. 69-71.

[4] R.Kh. Gairabekov, F.S. Turlova, Some factors of pathogenicity of Serratia bacteria, in Natural and technical sciences, 4(54) (2011) 163-169.

[5] R.Kh. Gairabekov, R.A. Achaev, E.S. Erzhapova, R.S. Erzhapova, Some factors of pathogenicity of 
Enterobacter cloacae cultures isolated from sheep in associative helminthic-bacterial diseases, South of Rus.: ecol., develop. 5(3) (2010) 100-102.

[6] R.Kh. Gairabekov, E.S. Erzhapova, F.S. Turlova, Z.E. Umieva, Some properties of Escherichia coli cultures isolated from sheep in associative helminthic-bacterial diseases, South of Rus:: ecol., developm. 5(4) (2010) 83-86.

[7] R.Kh. Gairabekov, Characteristics of Serratia marcescens bacteria isolated from sheep during postdeworming dysbacteriosis in the Chechen Republic, Bull. of the Saratov State Agrar. Univ. named after N.I. Vavilov 4 (2010) 3-5.

[8] R.Kh. Gairabekov, R.Kh. Gairabekova, Ya.A. Gaisumov et al., Some features of the epizootic process in enterobacteriosis of small ruminants in the Chechen Republic, Refleks. 4 (2019) 6-12.

[9] R.Kh. Gairabekova, Pathogenic and opportunistic bacteria in home-produced milk and dairy products Refleks. 1 (2019) 19-23.

[10] R.Kh. Gairabekova, Z.M. Tsentroev, Pathogenic streptococci, staphylococci and opportunistic enterobacteria in home-produced milk and dairy products, Bull. of the Med. Inst. 15(1) (2019) 5258.

[11] F.S. Turlova, R.Kh. Gairabekov, Production of hemolysins by Serratia bacteria isolated from various sources in the Chechen Republic, Bull. of the Chech. State Univ. 1(17) (2015) 126-128. 